\title{
Corporate social performance and stock returns: UK evidence from disaggregate measures
}

Article

Accepted Version

Brammer, S., Brooks, C. and Pavelin, S. (2006) Corporate social performance and stock returns: UK evidence from disaggregate measures. Financial Management, 35 (3). pp. 97116. ISSN 1755-053X doi: https://doi.org/10.1111/j.1755053X.2006.tb00149.x Available at https://centaur.reading.ac.uk/20507/

It is advisable to refer to the publisher's version if you intend to cite from the work. See Guidance on citing.

Published version at: http://dx.doi.org/10.1111/j.1755-053X.2006.tb00149.x

To link to this article DOI: http://dx.doi.org/10.1111/j.1755-053X.2006.tb00149.x

Publisher: Wiley

All outputs in CentAUR are protected by Intellectual Property Rights law, including copyright law. Copyright and IPR is retained by the creators or other copyright holders. Terms and conditions for use of this material are defined in the End User Agreement.

www.reading.ac.uk/centaur 
Central Archive at the University of Reading

Reading's research outputs online 
This is the authors' accepted manuscript of an article published in Financial Management. The definitive version is available at www3.interscience.wiley.com 


\title{
Corporate Social Performance and Stock Returns: UK Evidence from Disaggregate Measures
}

\author{
Stephen Brammer \\ University of Bath
}

\author{
Chris Brooks* \\ Cass Business School
}

\author{
Stephen Pavelin \\ University of Reading
}

\begin{abstract}
This study examines the relationship between corporate social performance and stock returns in the UK. Using a set of disaggregated social performance indicators for environment, employment and community activities, we are able to more closely evaluate the interactions between social and financial performance than would be the case for an aggregate measure. While scores on a composite social performance indicator are significantly negatively related to stock returns, we find that the poor financial reward offered by such firms is attributable to their good social performance on the employment and to a lesser extent the environmental aspects. Interestingly, we find that considerable abnormal returns are available from holding a portfolio of the socially least desirable stocks. These relationships between social and financial performance cannot be rationalised by multi-factor models for explaining the crosssectional variation in returns or by industry effects.
\end{abstract}

January 2006

Keywords: Corporate social responsibility, ethical investing. stock returns, trading rule performance.

JEL Classifications: G10, G14, M14, M20

\footnotetext{
* Corresponding author. Faculty of Finance, Cass Business School, City University, 106 Bunhill Row, London EC1Y 8TZ, UK. t: (+44) (0) 207040 5168; f: (+44) (0) 207040 8881;

e-mail C.Brooks@city.ac.uk .
} 


\section{Introduction}

There are now a large and growing number of ethical mutual funds in the US, Canada, and Europe. According to the US Social Investment Forum, over $10 \%$ of all equity investment is currently managed under the guidelines for Socially Responsible Investment (SRI). SRI is related to the concept of corporate social responsibility (CSR), and the former often involves a fund implementing "ethical screens" to ensure that it does not invest in firms that have poor records in the latter. Many large mutual funds and pension funds now include ethical criteria in their stock selection processes, and there is evidence that analysts are under pressure to produce research on SRI issues ${ }^{1}$.

While the number of academic studies in this area has also increased substantially in recent years, no clear consensus has yet emerged concerning whether investment in socially responsible stocks or funds is favourable or detrimental to returns. From a theoretical perspective, one line of argument associated with the efficient markets hypothesis would suggest the following logic concerning the merits or otherwise of SRI. At the individual firm level, under some assumptions concerning the existence of markets and well-defined property rights, an equilibrium should develop whereby engaging in expenditure on socially responsible activities takes place up to the point where its marginal profitability is zero. Thus, the returns to socially responsible and irresponsible firms should be the same, for given levels of risk and other firm characteristics.

At the portfolio level, however, if this argument concerning the neutrality of corporate responsibility for returns holds, then investors must be made unambiguously worse off by the screening-out process. Removing some stocks, sectors, or even whole countries on ethical grounds from the investable universe of securities will reduce portfolio efficiency. Looking at this issue from another angle, for investors who hold a well-diversified spread of assets to remain no worse off as a result of their social consciences, the remaining socially responsible firms' stocks must on average outperform their unscreened counterparts.

Finally, third line of argument suggests that enhanced corporate social responsibility should lead to enhanced returns. Several possible reasons for this are outlined in Section 3, and all relate to an improvement in the firm's operating performance, which may feed through to its stock price.

\footnotetext{
1 “Big investors want SRI research”, Financial Times Fund Management Supplement, 18 October 2004, p1.
} 
Hence, in theory at least, it is possible to justify either a positive or negative or no relationship between a firm's social performance and its financial performance.

The European Commission (2001) defines corporate social responsibility as "a concept whereby companies integrate social and environmental concerns in their business operations and in their interaction with stakeholders on a voluntary basis". But it is important to recognise that corporate social performance is multi-dimensional, and therefore focusing attention on the wrong aspect may yield inappropriate inferences. Having a social conscience may enhance a firm's profitability by helping to satisfy its stakeholders (employees, altruistic shareholders, consumers, government). Brammer and Pavelin (2005) show that a strong CSP may enhance or damage a firm's reputation depending upon how important that particular type of activity is to the stakeholders. A firm's level of corporate social responsibility may be measured along a number of different dimensions, including philanthropic activities, reduction of adverse environmental impacts, good treatment of employees, and to our knowledge, no single study has yet examined the differential impacts of each of these aspects of CSR on stock returns.

Our research employs data at the firm level, rather than at the fund level, which we argue is highly desirable. It is more than possible that previous studies using data on ethically responsible funds would confuse corporate social performance with fund manager performance. For example, it may be that on average, socially responsible firms do yield higher stock returns than socially reprehensible firms, but that ethical fund managers are poor stock pickers, or have systematically higher costs than standard funds. To the extent that talented fund managers with strong performance records are head-hunted to work for large, prestigious funds, the problem of disentangling these effects is likely to be confounded by the fact that most socially responsible funds are small. To summarise our findings in brief, this paper observes that firms scoring highly on ethical criteria appear to represent poor investments. Thus, our research lends support to the notion that findings of ethical fund underperformance may be the result of bad stocks rather than bad fund managers.

The remainder of this study unfolds as follows. Section 2 discusses the existing evidence on the relationships between CSR and firm financial performance, while the data that we employ are described and examined in Section 3. Section 4 presents the methodology employed while Section 5 contains the results and analysis. Section 6 offers some concluding remarks and suggestions for further research. 


\section{Corporate social responsibility and financial returns: the existing evidence}

In this section, we review the existing evidence concerning the links between corporate social responsiveness and stock market performance. It should be recognised that a significant body of work examines the link between social responsibility and accounting-based indicators of financial performance (Orlitzky et al., 2003; Griffin and Mahon, 1997). Since our concern lies with the impact of social responsibility on investors, upon whom accounting-based measures have only an indirect impact, we concentrate upon the studies concerning stock market performance. The literature that we review consists of three principal strands: evidence at the firm-level relating to assessments of firm reputation and stock performance; evidence at the fund-level concerning the relative performance of SRI and non-SRI funds; evidence at the firm-level regarding the relationship between social performance and stock returns. We consider each strand in turn.

Several papers have investigated the relationship between a firm's degree of corporate social responsibility and its reputation. Enhanced corporate social performance may lead to improved stock returns either directly through cost reductions and productivity improvements, or indirectly through an improvement in the firm's overall standing that makes analysts more willing to recommend the stock and investors more willing to hold it irrespective of the firm's costs and revenues. For example, Filbeck and Preece (2003) examine the information content of Fortune's annual "best 100 companies to work for in America" survey results, using data for the period 19871999. This award considers the "work/family balance", as well as remuneration and a range of other issues. Both immediate price reactions on announcement of the contents of the list and long-term buy-and-hold abnormal returns are examined. The average market-adjusted abnormal return on the event day is a highly significant $4 \%$, while the average abnormal return for the following year is $11.8 \%$. A sample of non-award winning firms, matched by size and sector, is significantly outperformed by the award-winners over a 30-day event period for 2 of the 13 years, and for 8 of them over the one-year horizon. The positive results in this study are argued to be stronger than previous findings in large part because Fortune has such a wide readership.

A further study that examines the relationship between reputation and returns is that by Antunovich and Laster (2000), who employ data for the 1983-1996 period from the US survey conducted each year by Fortune magazine in producing its list of "America's Most Admired Companies". Sorting the sample by scores into deciles, they find that the stocks of the most admired firms yield positive abnormal returns of $3.2 \%$ in the following year and $8.3 \%$ over the following three years. The stocks of the decile of lowest-scoring firms yield negative abnormal returns of $8.6 \%$ in the following nine 
months, although there is a sharp reversal thereafter. Chung et al. (1999), on the other hand, find little evidence that highly rated firms outperform less admired firms on a risk-adjusted basis. They employ data for the slightly shorter 1990-98 period, but they examine the performance of only the very highest ranked 10 firms and the very lowest ranked 10 firms, rather than the 50-firm portfolios employed by Antunovich and Laster (2000). Therefore, the results of Chung et al. (1999) could have arisen as a result of significant idiosyncratic risk in their portfolios.

A large number of studies have empirically examined the link between SRI and returns by examining the performance of ethical mutual funds. Guerard (1997a) uses an early (and small) set of data and finds that there is little significant difference between the performances of socially screened versus unscreened investments. Kahn et al. (1997) show that divesture of tobacco stocks would have made little difference to typical investors' returns since allocations to such stocks is usually very small ${ }^{2}$, although from 1987 to 1996, the tobacco sector outperformed the S\&P 500 by an average of $7 \%$ per year. In a follow-up study to his previous work, Guerard (1997b) shows that investment screens to preclude environmental or alcohol/tobacco/gambling or nuclear stocks actually yield higher average returns than unscreened investments. However, his return calculations involve some stock selection using a model rather than an equally weighted investment in the screened or unscreened stocks.

Cox et al. (2004) and Graves and Waddock (1994) suggest, using UK and US data respectively, that poor corporate social performance leads to a reduction in the number of long-term institutional investors holding the firm's stock since such firms are likely to be "screened out". On the other hand, a view dating back to Rostow (1959), and Friedman (1970), and echoed by a number of other more recent studies, is that CSR may divert resources away from projects that would have had a greater impact on profitability (McWilliams and Siegel, 2001).

Using more recent data for 1990-98, Statman (2000) examines the performance of the Domini Social Index (DSI). This index is produced by Kinder, Lydenberg and Domini (KLD), and is the most widely quoted socially responsible index that provides a benchmark for the measurement of the performance of ethically screened funds. In pure return terms, the DSI slightly outperformed the S\&P over the period, although risk-adjustment led to a slight underperformance. Statman's

\footnotetext{
${ }^{2}$ The four tobacco companies that were members of the S\&P 500 during the late 1990's had a total capitalisation that was only around $2 \%$ that of the whole index.
} 
conclusion is therefore that "pooling investing power for something other than making money is no worse at making money than pooling it for money alone" (p.38).

Many early studies of the performance of ethical funds considered returns only and did not allow for differential levels of risk between ethical and standard funds. Hamilton et al. (1993), however, use the CAPM framework to examine the performance of 32 socially responsible mutual funds for the 10-year period commencing January 1981. They observe only two significant alphas out of the 32 (one positive and one negative), leading them to conclude that "the market does not price socially responsible characteristics" (p.66).

Using a more sophisticated multi-factor performance attribution model of the style proposed by Carhart (1997), Bauer et al. (2002) show that both German and US ethical funds underperform their benchmark in terms of their risk-adjusted returns, although similar UK funds achieve slight outperformance. The performance of ethical fund managers in all three countries have improved over time, leading the authors to propose that a "learning-effect" is at work. Such an effect would also be consistent with the size and prestige of ethical funds enhancing over time, enabling them to recruit increasingly talented managers. Interestingly, Bauer et al. (2002) also show that ethical funds are typically less exposed to market-wide movements but more exposed to growth stocks and small capitalisation stocks than are standard mutual funds.

The importance of employing an appropriate benchmark for ethical funds is further highlighted by Geczy et al. (2003). They show that the cost of ethical screens for passive investors who do not believe in fund manager skill or in the use of multifactor models to enhance returns is very small and of the order of a few basis points per month. But for investors who have skill in picking talented fund managers, or who use factor models, the cost of imposing ethical screens could be as large as $3-4 \%$ per year.

Barnett and Salomon (2002) argue that it is important to recognise that socially responsible mutual funds differ substantially according to the severity of the ethical screens that they use. Allowing for this heterogeneity enables them to reconcile the divergent viewpoints on the performance of ethical funds in the extant literature. Using 28 years of data on 67 socially responsible funds, Barnett and Salomon find a U-shaped relationship between performance and the strength of the screen. Funds that employ minimal screens are still able to diversify well, while funds that employ very strict screens are able to filter out poor quality firms effectively. However, funds that employ 
intermediate-level screens are found provide the weakest performance, neither forcefully weeding out firms to avoid nor being able to diversify sufficiently across the remaining firms in the investable universe.

Several studies examine the link between CSR and financial performance using theoretical rather than empirical models. These theoretical models of the impact of investment screening are related to Merton's (1987) model of market segmentation. Angel and Rivoli (1997) and Heinkel et al. (2001) consider the issue of SRI from a different perspective, and examine the impact of environmentally sound behaviour on a firm's costs of equity capital. It is argued that socially responsible investors will not invest in firms whose environmental policies are questionable, and therefore the demand for the shares of such firms will come only from "neutral" investors, i.e. those who form portfolios without a social conscience. This lack of demand will force up the cost of capital for polluting firms relative to green firms. Heinkel et al. conclude that the cost of reforming a polluter is a crucial variable, but that SRI at its current levels is unlikely to have had any significant impact upon firm behaviour.

Finally, there is virtually no evidence of the impact of social responsibility on stock returns at the firm level, aside from studies by Feldman et al. (1997) and by Derwall et al. (2004). The former focus on the environmental aspect of CSR only, and suggest that firms who are able to improve their environmental performance can reduce their CAPM betas and raise their stock prices by up to 5\%. Derwall et al. (2004) employ data from the Innovest rating database of "ecoefficiency" scores, which again cover only environmental issues, for the period 1995-2003. They rank their sample of companies with ecoefficiency scores and form them into two portfolios comprising the highest and lowest scoring companies. Whether a CAPM framework or a multifactor model incorporating industry effects and other portfolio characteristics is used to account for differences in risks, the high-scoring portfolio significantly outperforms the low-ranking one.

\section{Data}

\subsection{EIRIS Data}

The Ethical Investment Research Service (EIRIS) specialise in the measurement of corporate social performance against an objective set of criteria, principally for use by institutional investors. EIRIS survey firms concerning their social performance, but also undertake their own research. As a result, they are able to provide social performance scores for a firm irrespective of whether it participates in their survey. EIRIS engage in a process of updating their data on a more or less 
continuous basis, making the distribution of scores fairly stable over time. Each company is examined at least twice annually, and significant pieces of information are added to a company's profile as they happen. Our data were drawn from their database in June 2002. The ratings are based on fairly objective, quantifiable criteria (such as the number and size of environmental fines, or the proportion of women on the firm's Board). Although issues relating to employment, the environment, community, human rights and supply chain management are all covered, due to the limited availability of data regarding the last two, we restrict our attention to the first three of these dimensions of social performance.

The indicator of employee responsibility is based upon six measures relating to health and safety systems, systems for employee training and development, equal opportunities policies, equal opportunities systems, systems for good employee relations, and systems for job creation and security. The environment variable comprises three measures, which are the quality of environmental policies, environmental management systems, and environmental reporting. Finally, our indicator of community responsiveness is measured as a single variable. Following Graves and Waddock (1994), we translate each of the text ratings into quantitative variables. Each employment measure has four text ratings, the environment variables have five text ratings, and the community variable has four text ratings, which were all transformed into integer scales beginning with 0 and ending in 3, 4 and 3 respectively. Thus, to summarise, the three measures of social performance that we use are:

- Community performance, graded 0 to 3 .

- Environmental performance: 3 categories (policies, management systems, and reporting), each rated from 0 to 4 , yielding a total environmental responsibility score out of 12 .

- Employee performance: 6 categories (health and safety, training and development, equal opportunities policies, equal opportunity systems, employee relations, systems for job creation and job security) each rated from 0 to 3 , yielding a total employee responsibility score out of 18 .

To arrive at a single aggregate measure (termed CSR in our subsequent regressions), we normalised the three scores to a 0 to 3 scale, and then summed them, generating an overall score out of 9 .

The availability of disaggregate data on various aspects of CSR performance is likely to be important since CSR is mutli-faceted these various aspects may have differential impacts depending on the nature of the firm's business. Some CSR projects can directly reduce operating costs - for 
example, reducing the use of agrochemicals or employing energy-saving technology. On the employee relations side, it is possible that practices such as flexible scheduling to allow workers to achieve desirable work-life balances may enhance productivity, reduce absenteeism, and may make it easier to recruit and retain high calibre staff (Turban and Greening, 1997). Visible funding of or involvement in community projects may also strengthen brand images, engendering a sense of loyalty among consumers. Finally, companies with good records on CSR issues may be less subject to stringent regulatory oversight, enabling them to focus more time and energy on strategic business issues. There is also evidence that awareness and consideration of environmental and employee issues may reduce the potential for costly lawsuits (Ullman, 1985).

Examining first some descriptive statistics for the EIRIS data in the first panel of Table 1, a large number of companies appear to achieve zero scores for some or all measures. Of the 451 companies in our sample, 296 (66\%) have scores, while the remainder do not. Not having a score cannot be taken necessarily to imply poor social performance, and probably relates predominantly to firm size since most of these firms are relatively small. At the other end of the CSP spectrum, the number of companies achieving top scores varies from one measure to another. Too many firms to list achieve the highest possible ratings for the community indicator, but the top firms for other measures are dominated by banks (e.g., Abbey and Northern Rock), oil or energy companies (e.g., BP, Shell, British Energy), and manufacturing firms (e.g., Cable \& Wireless, Unilever).

Clearly, firms' social performance achievements vary significantly across sectors, as further indicated in Panel B of Table 1. This was expected since some industrial sectors have high environmental impacts (e.g., power generation, resources, chemicals), and it is likely that environmental performance may be more important in such sectors. In other sectors, including retailing and light manufacturing, the treatment of workers will probably have higher importance. For firms where brand reputation is crucial, charitable giving and community work may provide greater impacts than other aspects of CSR.

As the table shows, for the environmental aspects of CSR, the utilities and resources firms score highly, supporting the view that such considerations are now viewed as highly important in these traditionally dirty sectors. Interestingly, utilities and resources firms also score most highly under all other measures, and therefore also under the composite statistic. The worst performing sectors by some margin are information technology, cyclical consumer goods, and general industrials. It may be that differing levels of CSP across sectors reflects the levels of operating profitability in those 
sectors, so that highly profitable industries may have the luxury of expending funds on activities that will enhance CSP scores. On the other hand, highly competitive and less profitable sectors such as general industrials may appreciate the benefits of behaving in a socially responsible manner, but they may not be able to afford to take the necessary measures.

\section{$\underline{3.2 \text { Other Variables }}$}

Our sample comprises all firms that were constituents of the FTSE All Share Index as of July 2002. This index is a market-capitalisation weighted index of UK quoted firms. We obtained data from Datastream on all firms that were index constituents at that time for the following variables: share total return indices (i.e. with dividends added back), market value of equity, book value, and industry code. After excluding investment trusts, and companies for which either the Datastream codes or one of the required variables was missing, we were left with a total of 451 firms plus the All Share Index itself.

A matrix of correlations between each of the variables employed in this study is presented in the last panel of Table 1. We examine these correlations first to check for strong relationships that may cause near multicolinearity in our subsequent regressions, and second, to determine whether there are any associations between the social performance indicators and the other variables. The most salient feature of the correlation matrix is the very high degree of association within the set of CSP scores. For example, the employment and community variables have a correlation of 0.68 . Also, as one would expect, the composite measure is highly correlated with all of its components. As a result, we will employ the composite measure in separate regressions from the 3 component variables.

All of the performance attribution financial variables (beta, price-to-book, market capitalisation, the previous year's return) have negligible correlations with the CSP variables except for market capitalisation. Confirming our intuition, all else being equal, large firms are likely to achieve higher CSR scores than small firms, although the association is not very strong ${ }^{3}$.

\footnotetext{
${ }^{3}$ A regression analysis of the determinants of the scores under each social responsibility indicator confirms the finding that market capitalisation positively affects each of the scores, so that large firms are more likely to score highly however corporate social performance is measured. None of the other factors employed in this study (CAPM beta, price-to-book value or previous year's return) significantly affect the scores under any CSR category, and therefore these results are not shown to preserve space but are available from the authors on request.
} 


\section{Methodology}

Some previous studies of corporate social performance have investigated both short-run price impacts following announcements of new CSR data, and long-run stock return performances for one or more years following the announcement. However, an examination of the short-run price impact is not feasible in our study since the EIRIS data are updated on a continuous rather than discrete basis and therefore there is no event date as such. Thus we focus on long run stock returns over 1 and 2 years following the cut-off date at which the data were collected.

Our first step is to examine the returns to various portfolios formed on the basis of differing levels of corporate social responsibility scores, comparing them with the FTSE 100 and FTSE All-Share as benchmarks. The portfolios are all equally weighted (apart from the FTSE benchmarks), and assume initial investment on 1 July 2002 for a 1- or 2-year holding period. We also investigate the returns of quintile portfolios separately formed on the basis of each measure of social performance. This procedure ensures that a reasonable size of portfolio is examined in each case, and that all of the portfolios contain the same number of firms to ensure a valid comparison.

Next, we run a cross-sectional regression of the stock returns on the composite CSP measure and separately on the three constituent indicators (environment, employment, and community). This enables us to disaggregate the effects of the various aspects of CSP on returns, and to determine whether there are any differences between them:

$$
r_{i, t}=\alpha_{0}+\alpha_{1} C S R_{i, t-1}+\alpha_{2} E N V_{i, t-1}+\alpha_{3} E M P_{i, t-1}+\alpha_{4} C O M M_{i, t-1}+u_{i, t}
$$

where $r_{i, t}$ are the returns to stock $i$ in year $t$ (where each year runs from $1 \mathrm{July}$ ), CSR is the composite measure, $E N V$ is the environment indicator, EMP is the employment indicator, COMM is the community indicator, $u_{t}$ is a disturbance term, and either $\alpha_{1}=0$ or $\alpha_{2}, \alpha_{3}, \alpha_{4}=0$.

It is important to consider firm characteristics when examining the relationship between stock return performance and CSP since high-scoring firms were found typically to be large, and the stock returns of large firms are on average lower than those of small firms (see, for example, Fama and French, 1992). Thus, we wish to examine the relationship between CSP and returns after allowing for firm characteristics. So, suppose that we observe companies that have scores yield large abnormal returns. Does this exceptional performance directly follow from their good social performance, or does it arise, for example, because such firms have large exposures to a momentum factor and stocks with momentum usually outperform in the following year? In order to answer this 
question, we re-run regression (1), but additionally including the four standard performance attribution factors:

$$
\begin{aligned}
& r_{i, t}=\alpha_{0}+\alpha_{1} C_{S R} R_{i, t-1}+\alpha_{2} E N V_{i, t-1}+\alpha_{3} E M P_{i, t-1}+\alpha_{4} C O M M_{i, t-1}+\alpha_{5} P T B V_{i, t-1}+\alpha_{6} B E T A_{i, t-1} \\
& +\alpha_{7} C A P_{i, t-1}+\alpha_{8} r_{i, t-1}+u_{i, t}
\end{aligned}
$$

We therefore regress the returns on a constant, the CAPM beta, firm size ("CAP"), price-to-book value ("PTBV'), beta, and the previous year's return. These explanatory variables are the FamaFrench factors, plus a measure of momentum. The latter is employed following work by Carhart (1997) suggesting that firms experiencing strong performance over periods up to one year are likely to continue to do so in the short term.

Finally, as suggested above, it may be the case that the relationship between stock returns and CSP varies across sectors so that activities regarded as best practice in some industries are viewed as wasteful and value-destroying in others. We do this by running the following regression separately for each sector:

$$
r_{i, t}=\alpha_{0}+\alpha_{1} E N V_{i, t-1}+\alpha_{2} E M P_{i, t-1}+\alpha_{3} C O M M_{i, t-1}+u_{i, t}
$$

Note that, in order to avoid repetition, only the individual social performance indicators and not the composite measure are employed in this model.

\section{Results}

Table 2 presents some average return figures for various equally weighted portfolios formed on the basis of their corporate social performance scores and held for 1 or 2 years. The number of firms that would be contained in each of these portfolios is also listed in the final column. The 1-year returns are all negative, except for that for firms with zero scores on all measures. The predominance of negative returns arises from the fact that world equity markets fared badly at that time (July 2002 - June 2003). However, these results also show that firms with high scores on any

of the measures have significantly lower average returns than the benchmarks. For example, investing equally in the four firms with top employment scores would have yielded a return $24 \%$ lower than the FTSE benchmark. While this portfolio is clearly very small, and therefore its returns will be subject to strong idiosyncratic effects, it is telling that the top-performing firms under all CSP measures provide negative abnormal returns. Also interesting, and confirming the finding that bad firms from a social responsibility standpoint provide good investments, is the fact that the portfolio comprising the 17 firms with zero scores on every measure actually yields a positive return of almost $8 \%$, outperforming the benchmarks by $20 \%$. 
The 2-year returns in Table 2 paint a broadly similar picture, with the firms scoring highest on the composite CSR measure underperforming the FTSE. Examining the highest scoring firms according to the individual constituent indicators shows that the best scoring firms on environmental and employment grounds considerably underperformed the benchmark, although the top scorers on the community measure outperformed it by $4 \%$ over 2 years. Firms with scores of zero on every measure yield a remarkable abnormal return of $60 \%$ over 2 years.

However, the results in Table 2 only examine the performance of the highest scoring firms, and consequently the number of firms included in the analysis is typically small. In order to consider the impact of corporate social performance in more detail, Table 3 presents the 1- and 2-year returns for quintile portfolios formed on the basis of the ranked social performance scores. Decile 1 contains the $20 \%$ of firms with the lowest scores, and so on, while decile 5 contains the highest scoring firms under each measure. Whether a 1- or 2-year horizon is examined (Panels A and B of Table 3 respectively), and which ever CSR measure is utilised, the financial dominance of the worst performing firms on social grounds is evident. There is a modest and almost monotonic decline in performance as the CSR score increases, although quantitatively, there is little difference between the average returns for firms in quintiles 2 to 5 .

Tables 4 and 5 present the results of regressions of returns on the various measures of CSP for the 1- and 2-year holding periods respectively. These regressions include all companies in our sample that have (zero or non-zero) CSP scores. The parameter estimates and their levels of significance show a high degree of stability across the two investment horizons. Examining first the relationship between the composite performance measures and returns, it is evident that a higher score leads to a statistically significantly lower average return. Each 1-point increase in the score leads to a fall in returns by around $1.7 \%$ per year, so that the difference between the expected returns for the highest and lowest scoring firms based on the overall CSP measure is around $15 \%$ per year.

Examining each social performance indicator separately, the next row in Tables 4 and 5 presents the results of a regression on the 3 constituents. It is evident that high scores on either the environment or the employment indicators leads to lower returns, although only the employment parameter is significant at the 5\% level. Investing in forms with the highest scores on the employment variable (14 on an 18-point scale) would on average yield returns $15 \%$ per annum lower than investing in 
firms with zero scores on this measure. On the other hand, higher community indicator scores lead to higher returns on average, but not significantly so.

In order to determine whether the poor performance of highly scoring firms may be attributable to the other characteristics of such firms, the final two rows of Tables 4 and 5 include the four standard risk factors. Among these, only the momentum factor is consistently significant, and has a positive sign suggesting that firms which had performed well in the previous year will typically continue to do so. But incorporating these variables into the regressions does not affect either the sizes or the significances of the CSP measures.

Table 6 examines the relationships between financial and social performance at the 1- and 2-year investment horizons separately for each industrial sector. The numbers of firms in some of the sectors, presented in the final column of the table, are somewhat small (notably IT, utilities, resources, cyclical consumer and non-cyclical services), inevitably increasing the standard errors and therefore adversely affecting the statistical significance of the parameters for those sectors. However, perhaps surprisingly, there is very little difference between the impacts of the various CSP indicators on returns between the sectors. At the 1-year horizon, the environment variable negatively affects returns for all 10 sectors, although only significantly so for 3 of them, while the employment variable only negatively and significantly affects returns for the resources sector; the parameter is positive for the basic industries, non-cyclical consumer, general industrials and noncyclical services sectors, although never significantly so. Finally, the community indicator has a positive impact for 8 of the 10 sectors, but again it is never statistically significant. Buying the stocks of firms with poor social performances yields the most striking benefits in the case of the general industrials sector, where buying firms with the lowest environmental score and the lowest community score would lead to average returns $70 \%$ higher and $30 \%$ higher respectively than firms with the highest scores.

\section{Conclusions}

This paper has investigated the relationship between corporate social performance and financial performance, measured using stock returns, for a sample of UK quoted companies. Our main finding is that firms with higher social performance scores tend to achieve lower returns, while firms with the lowest possible CSP scores of zero considerably outperformed the market. While we only have one set of social performance indicators at our disposal, our dataset contains an unusually high quality of disaggregate data that enables us to distinguish the differential impacts of the 
various aspects of social performance. We observe that the environmental and employment indicators are negatively correlated with returns while the community indicator is weakly positively related. Neither factor models of the Fama-French variety nor industry effects are able to explain the low returns offered by the highest scoring firms, and our results thus lend weight to the argument that expenditure on corporate social activities is largely destructive of shareholder value (Navarro, 1988). Our findings are clearly relevant to equity analysts and fund managers considering the implementation of ethical screens in suggesting that this will dent their performance.

Given the fact that the differences in returns between socially responsible and socially reprehensible firms are so great, and cannot be explained by standard risk-based models, one is forced to consider behavioural explanations. It may be the case that altruistic private or institutional shareholders are willing to forgo returns in order to feel morally at ease with the stocks that they hold, so that required returns on the stocks of socially responsible firms are lower. Equally, it may be the case that expenditure on CSR affects the bottom line negatively and thus the share prices of firms that engage excessively in such activities are punished by the financial markets over the longer term, and shareholders are slow to realise this. Even if an improvement in an individual firm's social performance is rewarded by a one-off share price increase by an over-exuberant equity market in the short term, cross-sectionally, the relationship between social and financial performance may be negative. Future research may be able to shed light on the relative merits of these competing explanations of our results, or may conduct event studies to examine in a time-series context the impact on its share price of a change in corporate social policy by a firm. 


\section{References}

Angel, J.J. and Rivoli, P. (1997) Does Ethical Investing Impose a Cost upon the Firm? A Theoretical Perspective Journal of Investing 6(4), 57-64.

Antunovich, P. and Laster, D.S. (2000) Do Investors Mistake a Good Company for a Good Investment? Journal of Investing Spring

Bauer, R., Koedijk, K., and Otten, R. (2002) International Evidence on Ethical Mutual Fund Performance and Investment Style Mimeo. Limburg Institute of Financial Economics, Maastricht University.

Barnett, M.L. and Salomon, R.M. (2002) Unpacking Social Responsibility: The Curvilinear Relationship between Social and Financial Performance Academy of Management Proceedings SIM: B1.

Brammer, S. and Pavelin, S. (2005) Corporate Reputation and Social Performance: the importance of fit Journal of Management Studies (In press).

Carhart, M. (1997) On Persistence in Mutual Fund Performance Journal of Finance 52, 57-82.

Chung, S.Y., Eneroth, K., and Schneeweis, T. (1999) Corporate Reputation and Investment Performance: The UK and US Experience Mimeo, University of Massachusetts, Amherst.

Cox, P., Brammer, S. and Millington, A. (2004) An Empirical Examination of Institutional Investor Preferences for Corporate Social Performance Journal of Business Ethics 52(1), $27-43$.

Derwall, J., Günster, N., Bauer, R., and Koedijk, K. (2004) The Eco-Efficiency Premium Puzzle Mimeo. Rotterdam School of Management, Erasmus University.

European Commission (2001) Promoting a European Framework for Corporate Social Responsibility Green Paper 264, Final, Brussels.

Fama, E. and French, K. (2002) The Cross-Section of Expected Stock Returns Journal of Finance 47, 427465.

Feldman, S.J., Soyka, P.A., and Ameer, P.G. (1997) Does Improving a Firm's Environmental Management System and Environmental Performance Result in a Higher Stock Price? Journal of Investing 6(4), 87-97.

Filbeck, G. and Preece, D. (2003) Fortune's Best 100 Companies to Work for In America: Do they Work for Shareholders? Journal of Business Finance and Accounting 30, 771-797.

Friedman, M. (1970) The Social Responsibility of Business is to Increase its Profits New York Times Magazine 13 September.

Geczy, C.C., Stambaugh, R.F. and Levin, D. (2003) Investing in Socially Responsible Mutual Funds Mimeo. Wharton School, University of Pennsylvania

Graves, S.B. and Waddock, S.A. (1994) Institutional Owners and Social Performance Academy of Management Journal 37, 1034-1046.

Griffin, J.J. and Mahon, J.F. (1997) The corporate social performance and financial performance debate: twenty five years of incomparable research. Business \& Society, 36(1), 5-31.

Guerard, J.B. Jr. (1997a) Is there a Cost to being Socially Responsible? Journal of Investing 6(2), 11-18.

Guerard, J.B. Jr. (1997b) Additional Evidence on the Cost of being Socially Responsible in Investing Journal of Investing 6(4), 31-35. 
Hamilton, S., Jo, H., and Statman, M. (1993) Doing Well While Doling Good? The Investment Performance of Socially Responsible Mutual Funds Financial Analysts Journal November, 62-66.

Heinkel, R., Kraus, A. and Zechner, J. (2001) The Effect of Green Investment on Corporate Behaviour Journal of Financial and Quantitative Analysis 36(4), 431-449.

Kahn, R.N., Lekander, C., and Leimkuhler, T. (1997) Just say no? The Investment Implications of Tobacco Divesture Journal of Investing 6(4), 62-70.

McWilliams, A. and Siegel, D. (2001) Corporate Social Responsibility: A Theory of the Firm Perspective Academy of Management Review 26, 117-127.

Merton, R.C. (1987) A Simple Model of Capital Market Equilibrium with Incomplete Information Journal of Finance 42(3), 483-510.

Navarro, P. (1988) Why do Corporations Give to Charity? Journal of Business 61, 65-93.

Orlitzky, M, Schmidt, F.L., and Rynes, S.L. (2003) Corporate Social and Financial Performance: A MetaAnalysis Organization Studies, 24(3), 403-441.

Rostow, E.V. (1959) To Whom and For What Ends is Corporate Management Responsible? in Mason, E.S. (ed.) The Corporation in Modern Society, Harvard University Press, Cambridge, Mass.

Statman, M. (2000) Socially Responsible Mutual Funds Financial Analysts Journal May 30-39.

Turban, D.B. and Greening, D.W. (1997) Corporate Social Performance and Organisational Attractiveness to Prospective Employees Academy of Management Journal 40, 658-672.

Ullman, A. (1985) Data in Search of a Theory: A Critical Examination of the Relationship Among Social Performance, Social Disclosure, and Economic Performance Academy of Management Review 10, 540-577. 
Table 1: Summary Statistics

Panel A: Companies Achieving Highest Scores for Each Measure

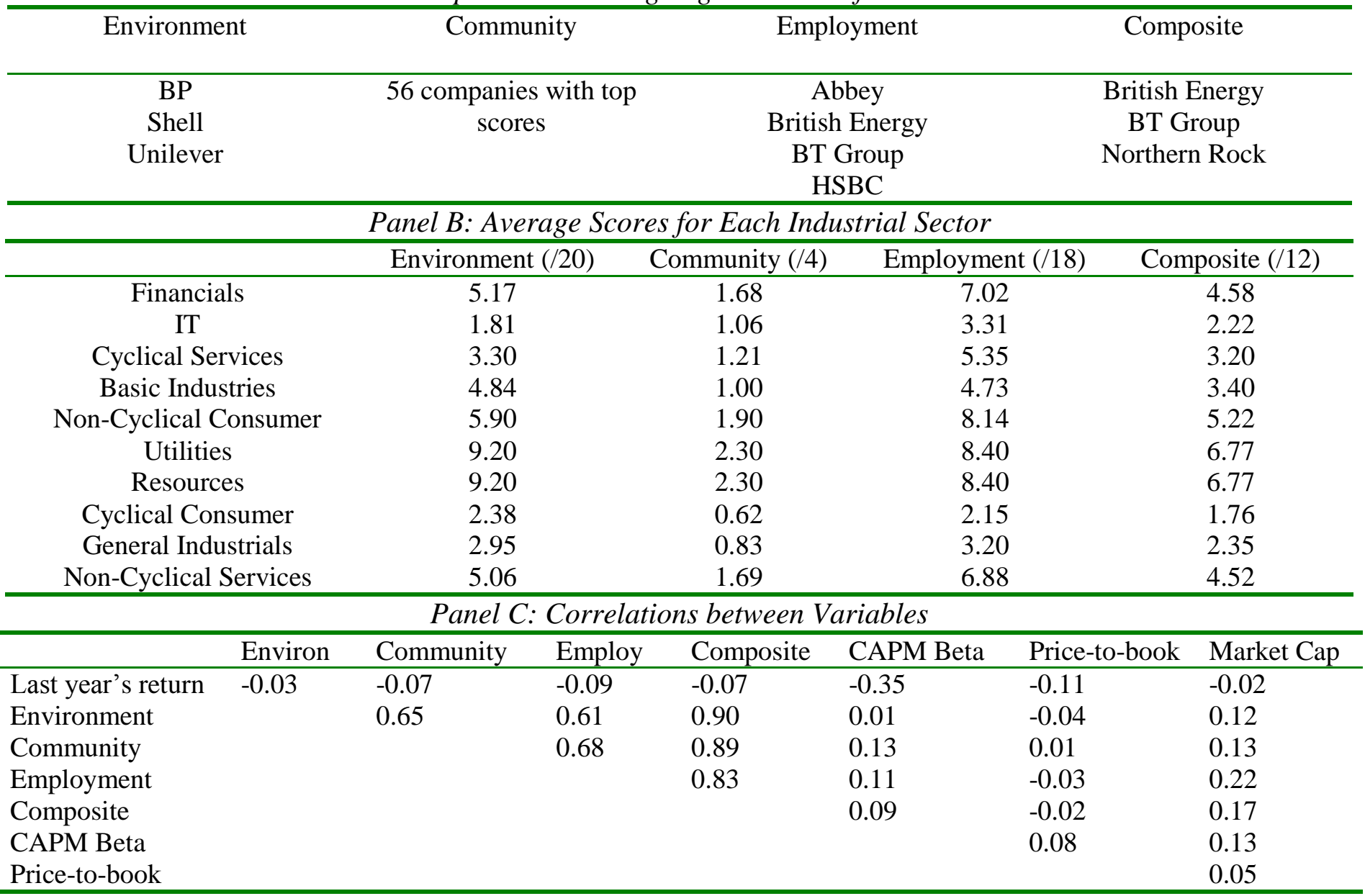

Table 2: Returns for various portfolios $(\%)$

\begin{tabular}{cccc}
\hline & 1-Year Return & 2-Year Return & Number of firms \\
\hline Firms with scores & -9.30 & 14.59 & 270 \\
Firms with non-zero scores on all measures & -9.78 & 12.08 & 185 \\
Unscored Firms & -7.55 & 30.14 & 155 \\
Firms with all zero scores & 7.86 & 65.06 & 17 \\
Top score environment & -20.21 & -8.35 & 3 \\
Top score community & -13.02 & 8.47 & 52 \\
Top score employment & -35.99 & -22.53 & 4 \\
Top score composite measure & -17.21 & 0.36 & 17 \\
FTSE 100 & -12.32 & 1.32 & 100 \\
FTSE All-Share & -11.58 & 4.09 & c. 600 \\
\hline
\end{tabular}


Table 3: Returns for Portfolios Based on Quintiles of CSR Scores (\%).

\begin{tabular}{ccccc}
\hline & \multicolumn{3}{c}{ Panel A: 1-Returns } \\
\hline & Environment & Community & Employment & Composite \\
Decile 1 (low score) & -0.50 & -4.97 & 2.08 & 2.00 \\
Decile 2 & -6.49 & -9.85 & -10.62 & -7.20 \\
Decile 3 & -10.29 & -8.42 & -8.04 & -15.26 \\
Decile 4 & -13.62 & -6.27 & -12.85 & -7.14 \\
Decile 5 (high score) & -10.62 & -12.34 & -12.02 & -14.39 \\
\hline \multicolumn{5}{c}{ Panel B: 2-Year Returns } \\
\hline & Environment & Community & Employment & Composite \\
Decile 1 (low score) & 30.46 & 32.99 & 41.35 & 39.20 \\
Decile 2 & 18.92 & 9.50 & 10.35 & 15.81 \\
Decile 3 & 12.41 & 11.21 & 12.24 & 4.71 \\
Decile 4 & 14.78 & 25.31 & 13.35 & 17.38 \\
Decile 5 (high score) & 10.81 & 8.21 & 10.51 & 9.85 \\
\hline
\end{tabular}

Table 4: Regression Results for 1-Year Returns

\begin{tabular}{|c|c|c|c|c|c|c|c|c|}
\hline$\alpha_{0}$ & $\alpha_{1}$ & $\alpha_{2}$ & $\alpha_{3}$ & $\alpha_{4}$ & $\alpha_{5}$ & $\alpha_{6}$ & $\alpha_{7}$ & $\alpha_{8}$ \\
\hline $\begin{array}{l}-1.409 \\
(2.705)\end{array}$ & $\begin{array}{c}-1.852 \\
(0.606)^{* *}\end{array}$ & - & - & - & - & - & - & - \\
\hline $\begin{array}{l}-1.081 \\
(2.740)\end{array}$ & - & $\begin{array}{l}-0.863 \\
(0.595)\end{array}$ & $\begin{array}{c}-1.087 \\
(0.548)^{*}\end{array}$ & $\begin{array}{c}1.990 \\
(2.313)\end{array}$ & - & - & - & - \\
\hline $\begin{array}{c}5.018 \\
(3.624)\end{array}$ & $\begin{array}{c}-1.829 \\
(0.592)^{* *}\end{array}$ & - & - & - & $\begin{array}{l}-0.267 \\
(0.197)\end{array}$ & $\begin{array}{c}-6.882 \\
(3.321)\end{array}$ & $\begin{array}{c}0.386 \\
0.266)\end{array}$ & $\begin{array}{c}0.187 \\
(0.042)^{* *}\end{array}$ \\
\hline $\begin{array}{c}5.767 \\
(3.632)\end{array}$ & - & $\begin{array}{c}-1.095 \\
(0.563)^{*}\end{array}$ & $\begin{array}{c}-1.033 \\
(0.526)^{*}\end{array}$ & $\begin{array}{c}2.648 \\
(2.202)\end{array}$ & $\begin{array}{l}-0.293 \\
(0.196)\end{array}$ & $\begin{array}{c}-7.532 \\
(3.336)^{*}\end{array}$ & $\begin{array}{c}0.411 \\
(0.268)\end{array}$ & $\begin{array}{c}0.183 \\
(0.042)^{* *}\end{array}$ \\
\hline
\end{tabular}

Notes: Cell entries are parameter estimates; standard errors in parentheses; $r_{i, t}$ are the returns to stock $i$ in year $t$ (where each year runs from $1 \mathrm{July}$ ), $C S R$ is the composite measure, $E N V$ is the environment indicator, $E M P$ is the employment indicator, COMM is the community indicator, $C A P$ is market capitalisation, $P T B V$ is price-to-book value, $u_{t}$ is a disturbance term; * and ** denote significance at the 5\% and $1 \%$ levels respectively; market capitalisation parameters and their standard errors have been multiplied by 10000 . 
Table 5: Regression Results for 2-Year Returns

$$
r_{i, t}=\alpha_{0}+\alpha_{1} C S R_{i, t-1}+\alpha_{2} E N V_{i, t-1}+\alpha_{3} E M P_{i, t-1}+\alpha_{4} C O M M_{i, t-1}+\alpha_{5} P T B V_{i, t-1}
$$
$+\alpha_{6} B E T A_{i, t-1}+\alpha_{7} C A P_{i, t-1}+\alpha_{8} r_{i, t-1}+u_{t}$

\begin{tabular}{ccccccccc}
\hline$\alpha_{0}$ & $\alpha_{1}$ & $\alpha_{2}$ & $\alpha_{3}$ & $\alpha_{4}$ & $\alpha_{5}$ & $\alpha_{6}$ & $\alpha_{7}$ & $\alpha_{8}$ \\
\hline 29.571 & -3.223 & - & - & - & - & - & - & - \\
$(4.899)^{* * *}$ & $(1.097)^{* *}$ & & & & & & & - \\
30.764 & - & -0.541 & -2.141 & 0.950 & - & - & - & \\
$(4.974)^{* *}$ & & $(1.087)$ & $(0.996)^{*}$ & $(4.187)$ & & & & \\
36.30 & -2.774 & - & - & - & -0.229 & -9.931 & 3.633 & 0.297 \\
$(6.570)^{* *}$ & $(1.072)^{*}$ & & & & $(0.357)$ & $(6.017)$ & $(4.820)$ & $(0.076)^{* *}$ \\
37.564 & - & -0.815 & -1.894 & 2.132 & -0.261 & -10.216 & 4.691 & 0.291 \\
$(6.610)^{* *}$ & & $(1.033)$ & $(0.960)^{*}$ & $(4.004)$ & $(0.357)$ & $(6.066)$ & $(4.864)$ & $(0.076)^{* *}$ \\
\hline
\end{tabular}

Notes: Cell entries are parameter estimates; standard errors in parentheses; $r_{i, t}$ are the returns to stock $i$ in year $t$ (where each year runs from $1 \mathrm{July}$ ), $C S R$ is the composite measure, $E N V$ is the environment indicator, $E M P$ is the employment indicator, $C O M M$ is the community indicator, $C A P$ is market capitalisation, PTBV is price-to-book value, $u_{t}$ is a disturbance term; $*$ and $* *$ denote significance at the $5 \%$ and $1 \%$ levels respectively; market capitalisation parameters and their standard errors have been multiplied by 10000 .

Table 6: Regression Results for 1-Year and 2-Year Returns by Sector $r_{i, t}=\alpha_{0}+\alpha_{1} E N V_{i, t-1}+\alpha_{2} E M P_{i, t-1}+\alpha_{3} C O M M_{i, t-1}+u_{t}$

\begin{tabular}{|c|c|c|c|c|c|c|c|c|c|}
\hline \multirow[b]{2}{*}{ Sector } & \multicolumn{4}{|c|}{$\underline{1 \text {-year returns }}$} & \multicolumn{4}{|c|}{ 2-year returns } & \multirow{2}{*}{$\begin{array}{c}\text { No. of } \\
\text { firms }\end{array}$} \\
\hline & $\alpha_{0}$ & $\alpha_{1}$ & $\alpha_{2}$ & $\alpha_{3}$ & $\alpha_{0}$ & $\alpha_{1}$ & $\alpha_{2}$ & $\alpha_{3}$ & \\
\hline Financials & $\begin{array}{l}2.644 \\
(6.261)\end{array}$ & $\begin{array}{l}-2.615 \\
\left(1.071^{*}\right.\end{array}$ & $\begin{array}{l}-0.403 \\
(1.072)\end{array}$ & $\begin{array}{l}4.271 \\
(4.872)\end{array}$ & $\begin{array}{l}38.389 \\
(10.269) * *\end{array}$ & $\begin{array}{l}-1.378 \\
(1.722)\end{array}$ & $\begin{array}{l}-0.255 \\
(1.731)\end{array}$ & $\begin{array}{l}-9.932 \\
(7.830)\end{array}$ & 39 \\
\hline IT & $\begin{array}{l}-9.260 \\
(13.162)\end{array}$ & $\begin{array}{l}-2.604 \\
(4.672)\end{array}$ & $\begin{array}{l}-1.390 \\
(4.870)\end{array}$ & $\begin{array}{l}5.682 \\
(14.294)\end{array}$ & $\begin{array}{l}16.659 \\
(13.440)\end{array}$ & $\begin{array}{l}-0.897 \\
(4.770)\end{array}$ & $\begin{array}{l}0.904 \\
(4.793)\end{array}$ & $\begin{array}{l}-10.737 \\
(14.597)\end{array}$ & 16 \\
\hline $\begin{array}{l}\text { Cyclical } \\
\text { services }\end{array}$ & $\begin{array}{l}-6.551 \\
(5.367)\end{array}$ & $\begin{array}{l}-0.071 \\
(1.353)\end{array}$ & $\begin{array}{l}-1.528 \\
(1.064)\end{array}$ & $\begin{array}{l}2.441 \\
(4.687)\end{array}$ & $\begin{array}{l}24.119 \\
(8.829)^{* *}\end{array}$ & $\begin{array}{l}-0.302 \\
(2.298)\end{array}$ & $\begin{array}{l}-3.703 \\
(1.751)^{*}\end{array}$ & $\begin{array}{l}8.892 \\
(7.740)\end{array}$ & 96 \\
\hline $\begin{array}{l}\text { Basic } \\
\text { industries }\end{array}$ & $\begin{array}{l}12.660 \\
(6.286)\end{array}$ & $\begin{array}{l}-2.851 \\
(1.270)^{*}\end{array}$ & $\begin{array}{l}0.925 \\
(1.118)\end{array}$ & $\begin{array}{l}-2.547 \\
(4.740)\end{array}$ & $\begin{array}{l}49.189 \\
(9.052)^{* *}\end{array}$ & $\begin{array}{l}-6.362 \\
(1.829)^{* *}\end{array}$ & $\begin{array}{l}1.174 \\
(1.610)\end{array}$ & $\begin{array}{l}1.652 \\
(6.825)\end{array}$ & 36 \\
\hline $\begin{array}{l}\text { Non-cyclical } \\
\text { consumer }\end{array}$ & $\begin{array}{l}-3.610 \\
(8.291)\end{array}$ & $\begin{array}{l}-1.761 \\
(1.203)\end{array}$ & $\begin{array}{l}0.307 \\
(1.117)\end{array}$ & $\begin{array}{l}0.829 \\
(4.272)\end{array}$ & $\begin{array}{l}2.057 \\
(12.190)\end{array}$ & $\begin{array}{l}-1.337 \\
(1.769)\end{array}$ & $\begin{array}{l}0.654 \\
(1.642)\end{array}$ & $\begin{array}{l}3.676 \\
(6.281)\end{array}$ & 28 \\
\hline Utilities & $\begin{array}{l}35.061 \\
(65.956)\end{array}$ & $\begin{array}{l}-2.341 \\
(7.373)\end{array}$ & $\begin{array}{l}-7.643 \\
(4.148)\end{array}$ & $\begin{array}{l}18.434 \\
(19.536)\end{array}$ & $\begin{array}{l}47.280 \\
(73.342)\end{array}$ & $\begin{array}{l}-1.968 \\
(8.198)\end{array}$ & $\begin{array}{l}-8.554 \\
(4.612)\end{array}$ & $\begin{array}{l}22.139 \\
(21.723)\end{array}$ & 10 \\
\hline Resources & $\begin{array}{l}49.644 \\
(14.283)^{*}\end{array}$ & $\begin{array}{l}-3.159 \\
(1.870)\end{array}$ & $\begin{array}{l}-4.924 \\
(1.420)^{*}\end{array}$ & $\begin{array}{l}6.482 \\
(4.610)\end{array}$ & $\begin{array}{l}281.322 \\
(157.618)\end{array}$ & $\begin{array}{l}-30.897 \\
(20.634)\end{array}$ & $\begin{array}{l}3.967 \\
(15.670)\end{array}$ & $\begin{array}{l}13.511 \\
(50.883)\end{array}$ & 9 \\
\hline $\begin{array}{l}\text { Cyclical } \\
\text { consumer }\end{array}$ & $\begin{array}{l}5.115 \\
(14.982)\end{array}$ & $\begin{array}{l}-3.411 \\
(5.960)\end{array}$ & $\begin{array}{l}-2.293 \\
(5.134)\end{array}$ & $\begin{array}{l}5.904 \\
(19.239)\end{array}$ & $\begin{array}{l}61.139 \\
(37.802)\end{array}$ & $\begin{array}{l}-11.923 \\
(20.989)\end{array}$ & $\begin{array}{l}0.092 \\
(15.914)\end{array}$ & $\begin{array}{l}0.995 \\
(48.338)\end{array}$ & 13 \\
\hline $\begin{array}{l}\text { General } \\
\text { industrials }\end{array}$ & $\begin{array}{l}9.852 \\
(7.581)\end{array}$ & $\begin{array}{l}-6.070 \\
(2.598) *\end{array}$ & $\begin{array}{l}1.294 \\
(2.267)\end{array}$ & $\begin{array}{l}-10.071 \\
(8.913)\end{array}$ & $\begin{array}{l}48.528 \\
(11.823)^{* *}\end{array}$ & $\begin{array}{l}-3.860 \\
(4.053)\end{array}$ & $\begin{array}{l}1.947 \\
(3.535)\end{array}$ & $\begin{array}{l}-21.911 \\
(13.900)\end{array}$ & 24 \\
\hline $\begin{array}{l}\text { Non-cyclical } \\
\text { services }\end{array}$ & $\begin{array}{l}7.543 \\
(19.590)\end{array}$ & $\begin{array}{l}-2.000 \\
(3.627)\end{array}$ & $\begin{array}{l}0.056 \\
(3.294)\end{array}$ & $\begin{array}{l}1.147 \\
(16.537)\end{array}$ & $\begin{array}{l}18.551 \\
(32.541)\end{array}$ & $\begin{array}{l}1.513 \\
(6.024)\end{array}$ & $\begin{array}{l}-4.051 \\
(5.473)\end{array}$ & $\begin{array}{l}11.165 \\
(27.470)\end{array}$ & 16 \\
\hline
\end{tabular}

Notes: Cell entries are parameter estimates; standard errors in parentheses; $r_{i, t}$ are the returns to stock $i$ in year $t$ (where each year runs from $1 \mathrm{July}$ ), $C S R$ is the composite measure, ENV is the environment indicator, EMP is the employment indicator, COMM is the community indicator, $u_{t}$ is a disturbance term; * and $* *$ denote significance at the $5 \%$ and $1 \%$ levels respectively. 